\title{
Substantiation of the complex of organizational and economic measures aimed at ensuring the energy efficiency of residential construction
}

\author{
Yulia Larionova ${ }^{1, *}$ \\ ${ }^{1}$ Moscow State University of Civil Engineering, Yaroslavskoye shosse 26, Moscow, 129337, Russia
}

\begin{abstract}
The present paper substantiates the relevance of scientific and methodological developments that allow correctly checking the compliance of actual energy efficiency indicators of residential buildings with specified parameters. The contradictions of the aims and economic interests of suppliers and end users of energy resources were revealed. The paper reasons the need to develop and implement a set of organizational and economic measures, which should be aimed at inducing individuals, developers, construction contractors and enterprises and the building materials industry, as well as at changing the current system of performance indicators of the Ministry of Energy of Russia, natural monopolies and resource-supplying companies.
\end{abstract}

\section{Introduction}

The strategic priority of Russia's economic policy in both the post-reform period and now is the creation and operation of real estate with active and widespread use of energyefficient and energy-saving technologies, building materials and structures.

Thus, within the framework of the "Energy Strategy of Russia for the period up to 2020" approved in 2003, the practical solution of problems in this sphere was linked with the forecast parameters of the development of the Russian national economy. In particular, in accordance with the "optimistic" scenario of the above-mentioned document, it was planned to reduce the energy intensity of GDP in 2005 by $14-15 \%$ to the level of 2000 ; in 2010 - by $25-27 \%$, in $2015-35-40 \%$, in $2020-42-46 \%$.

Of course, such a dynamics in the field of energy consumption should have been promoted by the pricing policy of natural monopolies concerning products and services. The developers assumed that an increase in prices in the natural monopoly sectors, outstripping the level of industry inflation, would lead to redistribution of profitability from the main energy-intensive consumers in favor of natural monopolies and create conditions for saving energy resources. Therefore, the planned outstripping growth of energy prices should stimulate energy saving in all sectors of the Russian national economy, including construction and housing and utility sector [1].

In the actual economic practice of functioning and development of the national economy in general and the construction industry, in particular, this should have meant

* Corresponding author: yuvladi@mail.ru 
changing existing technical and legal standards, rules and regulations determining the following: the consumption of fuel and energy in terms of tightening energy efficiency requirements; improvement of the rules for accounting and control of energy consumption; setting standards for energy consumption and marginal energy losses; mandatory certification of energy-consuming devices and equipment for mass application to establish their compliance with the established standards of energy consumption.

Two primary principles that can also be concerned to the construction industry should be pointed out from the Energy Strategy of Russia for the period up to 2020. The first is that the energy intensity of the construction should steadily decrease (the value of the created real estate object expressed in terms of units of equivalent fuel should be less year by year). The second is that a "planned" and steady increase in energy prices should stimulate energy savings.

However, the results of the research conducted by Russian scientists and experts in the field of energy saving in housing and utility services and improving the energy efficiency of housing construction [2, 3, 4] indicate that the government did not put forward regulatory requirements to reduce the energy intensity of construction in the period of 2003 - 2016. Meanwhile in the legal field, another problem was considered: a steady decline in operating energy usage, with a constant increase in tariffs for utilities, including heating costs.

At the same time, some of results of implementing the Energy Strategy in Russia for the period up to 2020 were presented within the framework of Energy Strategy of Russia for the period up to 2030. In particular, it was noted there that the country does not fully achieve the previously planned final quality results for the first stage of its implementation, since a number of issues were not fully resolved.

The developers considered that organizational and economic solution of these problems lied in the following actions: formation of an integrated and approved regulatory and legislative framework; creation of energy markets with a high level of competition and fair principles of trade organization; the completion of reforms that bring adjacent sectors of the economy to a new level of energy efficiency; transition from the leading role of the fuel and energy complex in the country's economy to the natural function of an efficient and stable supplier of fuel and energy resources for the needs of the economy and the population.

However, the authors assume [5,6] that the fundamental changes in the Russian ideology of energy efficiency were outlined, when the provisions of the Federal Law "On Energy Saving and Energy Efficiency Improvement ..." came into force (the Federal Law from 03.04.1996 N 28-FL "On Energy Saving" has lost its force after the introduction of it).

\section{Materials and Methods}

Today the relevant issue is the introduction of a fundamentally new concept of "energy efficiency", which is a relative value reflecting the ratio of the advantageous effect from energy resource using to the costs of energy resources produced in order to obtain such an effect, in relation to products, the technological process, a legal entity and an individual entrepreneur.

At the same time, the legislator emphasized that the energy efficiency requirements to buildings and structures should include indicators that characterize the specific value of energy consumption in buildings and structures. Approaches to the main criteria in the Federal Law "On Energy Saving" can be presented in the form of Table 1.

Thus, according to the line of current FL-261, the indicator of specific energy consumption cannot definitely determine the energy efficiency of the building, although it can be one of the components of energy efficiency. In this regard, energy costs that would reduce the specific energy consumption should be taken into account. 
Table 1. Comparative analysis of approaches to the main criteria formulated by the current and expired federal laws on energy saving.

\begin{tabular}{|c|c|c|}
\hline Term & FL-28 of 03.04.1996 & FL-261 of 23.11 .2009 \\
\hline Energy saving & $\begin{array}{l}\text { Realization of legal, } \\
\text { organizational, scientific, } \\
\text { industrial, technical and } \\
\text { economic measures aimed at } \\
\text { the effective use of energy } \\
\text { resources and the } \\
\text { involvement of renewable } \\
\text { energy sources in the } \\
\text { economic circulation }\end{array}$ & $\begin{array}{l}\text { Implementation of organizational, } \\
\text { legal, technical, technological, } \\
\text { economic and other measures aimed at } \\
\text { reducing the volume of energy } \\
\text { resources used while maintaining the } \\
\text { relevant beneficial effect from their } \\
\text { use (including the volume of products } \\
\text { produced, work performed, services } \\
\text { provided) }\end{array}$ \\
\hline $\begin{array}{l}\text { Energy efficiency } \\
\text { indicator }\end{array}$ & $\begin{array}{l}\text { Absolute or specific value of } \\
\text { consumption or loss of } \\
\text { energy resources for } \\
\text { products of any purpose } \\
\text { established by state standard }\end{array}$ & \\
\hline Energy efficiency & & $\begin{array}{l}\text { Characteristics reflecting the ratio of } \\
\text { the useful effect from the use of } \\
\text { energy resources to the costs of energy } \\
\text { resources produced in order to obtain } \\
\text { such an effect, in relation to products, } \\
\text { technological process, legal entity, } \\
\text { individual entrepreneur }\end{array}$ \\
\hline Energy efficiency class & & $\begin{array}{l}\text { Product characteristics, reflecting its } \\
\text { energy efficiency }\end{array}$ \\
\hline
\end{tabular}

For the solution of technical, organizational and economic problems of energy efficiency in 2016, in Russia new aims in the field of energy efficiency were set, which were reflected in the Roadmap for Improving the Energy Efficiency of Buildings and Structures that has two fundamental aspects:

- Firstly, the reduction of the payment load on the population for the housing and utility services by increasing the energy efficiency in the housing stock, performed among other means by carrying out major repairs of multi-apartment buildings and developing energy services in the housing stock;

- Secondly, the creation of an incentive system to improve the energy efficiency of buildings and structures.

The results of the researches on the organizational and economic issues of ensuring the energy efficiency for multi-apartment residential buildings of large Russian cities [7] show that the agenda of energy efficiency for housing construction comes from modern challenges of the functioning of this key economic sector under the global economic crisis, and particular energy crisis.

That is why the leaders of many Russian metropolises give a very close attention to this line in their work. They develop and improve legislation in this field; give precedence to financing and implementing targeted integrated programs aimed at improving the energy efficiency of housing construction and the development of utility infrastructure and energy saving; actively promote the idea of energy saving and energy efficiency in the housing sector among enterprises and population (hold various forums, conferences, official meetings).

For example, since 03.10.2011 the Government of Moscow has been implementing the State Target Program "Urban Planning Policy for 2012-2018", which, in addition to other aspects of urban development, sets out the requirements for indicators of energy efficiency of buildings and structures. The Resolution of the Government of Moscow from 25.01.2011 No. 18 "On Approval of the Rules for Establishing Energy Efficiency Requirements for 
Buildings, Structures and Facilities and Requirements for the Rules of Determining the Class of Energy Efficiency of Multi-Apartment Buildings" is also of great importance.

However, if targeting on energy efficiency indicators being absolutely fulfilled (for example, the requirements of the interstate standard GOST 31427-2010), the effectiveness of the work in this direction has rather large reserves of its growth. One of such reserves is the provision of correct monitoring and accounting of energy consumption in buildings under construction and, primarily, in operated residential buildings.

The results of the studies conducted by the authors of the present paper [8] indicate that new technologies introduced into the economic practice of housing construction and utility services without qualimetric assessment of their economic efficiency and qualified approbation often lead to increase in energy consumption, not to its decrease.

In this regard, the scientific and methodological developments that allow correctly verifying the compliance of actual energy efficiency indicators of residential buildings with specified parameters are becoming particularly relevant. Therefore, for the last years a number of scientists from OAO "NIIMosstroy" (including one of the authors of the present paper) have been working on establishing the reasons, why the objects being put into operation do not meet the requirements of energy efficiency. Based on this research, the scientists have already presented to the Government of Moscow a set of measures to eliminate the excess over the projected values of the actual energy consumption of the buildings put into operation.

\section{Results}

Studying the organizational-economic and technical problems of ensuring energy efficiency when building and operating multi-apartment houses, it should be mentioned that there was a try in Moscow to raise regulatory requirements for resistance to heat transfer of external enclosing structures in order to pursue the Presidential Decree N 889 of 4 June 2008 "On Some Measures to Improve the Energy and Environmental Performance of the Russian Economy" and the above-mentioned Federal Law-261 from 11.23.2009. In particular for walls that are not lower than $3.5 \mathrm{~m}$ since 01.10.2010 and 4,0 $\mathrm{m}$ - since 01.01.2016. Moscow City PP dated 05.10.2010 N 900-PP “On increasing the energy efficiency of residential, social and public buildings in the city of Moscow and amending the resolution of the Government of Moscow dated 09.06.2009 N 536- PP" was abrogated by decree of 06.12.2011 for N 583-PP.

Increased requirements for energy efficiency to residential and public buildings in Moscow were stated as "Information letter of M. Sh. Khusnullin, Deputy Mayor of Moscow in the Moscow Government No. 25.11-3073/2-2 dated 01.10.2012 ". It was addressed to the heads of organizations of the construction industry of the city of Moscow and defined the Target indicators for the first and second stages of reducing the energy intensity of the construction industry:

- for multi-apartment buildings with a height of more than 12 floors, since 2016 the total specific energy consumption should be $130 \mathrm{~kW} / \mathrm{h}$ (in the period from 2012 to 2015 $160 \mathrm{kWh} / \mathrm{m} 2$ ), including the specific energy consumption for heating and ventilation from 2016 to $65 \mathrm{~kW} \cdot \mathrm{h} / \mathrm{m} 2$ (in the period from 2012 to $2015-81 \mathrm{~kW} \cdot \mathrm{h} / \mathrm{m} 2$ );

- for social and public and business buildings, with a height of no more than 12 floors, since 2016 the total specific energy consumption should be $112 \mathrm{kWh} / \mathrm{m} 2$; in the period from 2012 to 2015 . - $140 \mathrm{kWh} / \mathrm{m} 2$ ), including the specific energy consumption for heating and ventilation from 2016 to $72 \mathrm{~kW} \cdot \mathrm{h} / \mathrm{m} 2$ (in the period from 2012 to $2015-90 \mathrm{~kW} \cdot \mathrm{h}$ $/ \mathrm{m} 2)$.

However, if comparing the "target indicators" (130 kWh/m2 and $65 \mathrm{kWh} / \mathrm{m} 2)$ and their "Basic level of specific annual consumption of energy resources in the apartment building" 
(Precept of 06.06.2016 No.399 - $242 \mathrm{kWh} / \mathrm{m} 2$ and $96 \mathrm{kWh} / \mathrm{m} 2$ ) with data empirically obtained during measurements of some multi-apartment residential buildings under construction and buildings in operation in Moscow, one can observe rather interesting unconformity. In particular, according to the indicator "the total specific annual consumption of heat energy for heating, ventilation, hot water supply, as well as for general house needs", Moscow's standards 1.86 times exceed all-Russian indicators (242/130), and in terms of "specific heat consumption for heating and ventilation" - 1,48 times (96/65).

The authors assume that comparing the principal provisions of the Russia's regulatory documents with similar provisions of European standards complemented by theoretical and experimental justification will allow the legislator to discover methodological and other unconformities. Meanwhile the results of comparing the actual data obtained, in particular, in Moscow apartment buildings put into operation within the last 3-5 years can be used for the finalizing (correcting) the existing house-building technologies in terms of compliance/non-compliance with their energy efficiency classes declared in their designs [9-12].

The models that were earlier and are currently developed by research staff from NIIMosstroy allow considering the influence of the following key characteristics on the specific energy consumption of multi-apartment residential buildings: heat input from sunlight in the heating season under Moscow's climate conditions; emissions of heat from household equipment in new buildings with different residential density; humidity of external walls and processes associated with their drainage, etc. The scientific value and practical significance of the results of research carried out in this field is that the data obtained will be tested and confirmed by the results of numerical, laboratory and field experiments and measurements.

When the research is completed, it is planned to develop a special program and methodology that allows organizing and conducting field studies of the multi-apartment houses that were put into operation. At the same time, the elements of the methodology for conducting experimental field studies, which are aimed at determining the reasons of exceedance of the actual consumption in residential buildings being put into operation over design values, will be based on the results of tests approbated on segments of enclosing structures in the climate chamber of the center of testing construction materials, products and structures in OAO NIIMosstroy.

\section{Discussion}

Resuming the consideration of problems of ensuring energy efficiency in the construction and operation of multi-apartment houses, it should be emphasized that the level of modern construction technologies and the production of building materials and structures, as well as the quality of "natural" measurements largely determine the effectiveness of state and regional policy in the field of energy saving and energy efficiency in residential construction and housing and utility services.

However, it is impossible to solve this technical problem using only technical (technological) solutions. The main reason is that the strategic goal of natural monopolies engaged in generating various types of energy, resource-supply organizations and the Ministry of Energy of Russia is to increase the volume of extraction and generation of traditional types of energy. (If judging not by aims that they declare on their sites, but by the performance of their activities). Meanwhile the final consumers of construction products aim at energy saving and energy efficiency. In other words, the strategic objectives of the central market participants do differ.

The resolution of this difference in objectives, economic interests and expectations, demands development and implementation of a set of organizational and economic 
measures that should be aimed at stimulating not only individuals, real estate developers, construction contractors, construction industry enterprises and construction materials industry, which are interested in it anyway. First of all this demands changing the existing systems of performance indicators for the Ministry of Energy of Russia, natural monopolies engaged in the generation of various types of energy, and resource-supplying organizations.

\section{Conclusion}

The technical problem of ensuring energy efficiency of residential construction and energy saving of multi-apartment house operation is really complicated and relevant for our country and demands the organizational and economic solution. The authors believe that in order to resolve the problem, the target indicators of the activities of the Ministry of Energy of Russia, natural monopolies engaged in the generation of various types of energy, and resource-supply organizations should be harmonized with objectives and aims of final energy consumers: contract construction organizations, developers, people, enterprises of building materials and structures.

\section{References}

1. Y. Larionova, A. Larionov, S.A. Pavlova, N.G. Gorshkov, Rynok dostupnoj zhiloj nedvizhimosti: voprosy gosudarstvennogo regulirovaniya: monografiya (SGU, Moscow, 2013)

2. M. Bauer, P. Mosle, M. Schwarz, Green Building. Guidebook for Sustainable Architecture (Springer, 2009)

3. A. Larionov, Journal of Applied Sciences 14, 2374-2379 (2014)

4. A. Larionov, E. Nezhnikova, ARPN Journal of Engineering and Applied Sciences 113, 2023-2029 (2016)

5. J. Panibratov, A. Larionov, World Applied Sciences Journal 23, 144-148 (2013)

6. R. Srinivasu, G.S. Reddy, S.R. Rikkula, International Journal of Reviews in Computing 5, 15-20 (2011)

7. Yu. Larionova, S.A. Pavlova, Life Science Journal 11(12s), 650-653 (2014)

8. A. Larionov, MATEC Web of Conferences 106, 09022 (2017)

9. A.K. Orlov, MATEC Web of Conferences 106, 08013 (2017)

10. M. Pasetti, S. Rinaldi, D. Manerba, A Virtual Power Plant Architecture for the Demand-Side Management of Smart Prosumers. Appl Sci-Basel, 8, 3 (2018), 432. DOI: 10.3390/app8030432

11. B. Marchi, S. Zanoni, M. Pasetti, 21st Summer School F. Turco of Industrial Systems Engineering, 13-15 September, 2016, Naples, Italy (2016).

12. S. Zanoni, B. Marchi, M. Pasetti, L. Zavanella, 2018 Industrial Efficiency Conference, 11-13 June 2018, Berlin, Germany (2018). 